\title{
PERAN LOCUS OF CONTROL, KEBUTUHAN BERPRESTASI DAN ENTREPRENEURSHIP
}

\author{
Asri Laksmi Riani \\ Fakultas Ekonomi dan Bisnis \\ Universitas Sebelas Maret \\ Email: asrilaksmiriani@yahoo.com
}

\begin{abstract}
The purpose of this study was to determine the role of personality traits (locus of control) and need for achievement in generating competitive advantage of small and medium-sized enterprises ( SMEs ). The population in this study is the owner/manager/staff enterprise (SME) in Surakarta. The sampling technique was convenience sampling, the respondents were willing to be successfully met and the study's respondents. The analytical used in this study is descriptive analysis. A total of 32 respondents, the obtained results: 1 . On the need for achievement, found that: all respondents enjoy their work, the majority of respondents enjoy and love to do challenging work, keep doing the job even though others have given up, and do not mind to work, while others have fun. 2. On the internal locus of control, found that: most of the respondents believe in the ability of self-determination, believe in control of his own plan, believe in control of his own life, believe in success due to his own abilities and skills, believe in the protection of self-interest.
\end{abstract}

Keywords: the need for achievement, internal locus of control, entrepreneurs, SMEs.

\begin{abstract}
ABSTRAK
Tujuan penelitian ini adalah untuk mengetahui peran ciri-ciri kepribadian (locus of control) dan kebutuhan berprestasi dalam menghasilkan keunggulan kompetitif perusahaan kecil dan menengah (UKM). Populasi dalam penelitian ini adalah pemilik/ manajer/staf perusahaan (UKM) di Surakarta dan sekitarnya. Teknik pengambilan sampel adalah convenience sampling, yaitu responden yang berhasil ditemui dan bersedia menjadi responden penelitian ini. Alat analisis yang digunakan di dalam penelitian ini adalah analisis deskriptif. Dari sebanyak 32 orang responden, maka diperoleh hasil, bahwa: 1. Pada kebutuhan untuk berprestasi ditemukan, seluruh responden menikmati pekerjaannya; sebagian besar responden menikmati dan senang melakukan pekerjaan yang menantang; tetap melakukan pekerjaannya meskipun orang lain telah menyerah; dan tidak keberatan untuk bekerja, sementara yang lain bersenang-senang. 2. Pada internal locus of control ditemukan bahwa, sebagian besar dari responden percaya pada
\end{abstract}


penentuan kemampuan diri sendiri; percaya pada kontrol atas rencana sendiri; percaya pada kontrol atas kehidupan sendiri; percaya pada kesuksesan karena kemampuan dan keterampilan sendiri; dan percaya pada perlindungan atas kepentingan diri sendiri.

Kata kunci: kebutuhan untuk berprestasi, internal locus of control, pengusaha, UKM.

Ciri-ciri kepribadian telah sering dilakukan dalam penelitian kewirausahaan, terutama studi pada usaha-usaha kecil (UKM), karena dianggap merupakan hal yang penting dan berpengaruh luas. Namun terdapat inkonsistensi antara teori dan temuan empiris tentang studi ciri-ciri kepribadian pada akhir 1980, yang menyebabkan adanya rekomendasi untuk menggeser minat penelitian pada pendekatan lebih berorientasi pada perilaku yang diharapkan untuk menjadi lebih produktif. Kurangnya dukungan empiris membawa konsekuensi pada kepentingan penelitian dengan pendekatan yang sensitif lingkungan dan menolak konsep ciri-ciri kepribadian.

Penolakan ini tidak membatasi kepentingan ciri-ciri kepribadian dalam penelitian kewirausahaan. Bahkan, penelitian kepribadian tetap sebagai pembelajaran utama yang diajarkan pada sebagian besar studi kewirausahaan. Namun, beberapa temuan empiris telah menyebabkan kegagalan dalam menyimpulkan peran ciri kepribadian dalam studi kewirausahaan. Hal ini dapat dilihat sebagai salah satu alasan yang menyebabkan penolakan ciri-ciri kepribadian dalam studi kewirausahaan. Berbagai alasan telah dilakukan untuk meyakinkan ciri-ciri kepribadian dalam studi kewirausahaan yang meliputi, inkonsistensi pengertian pengusaha dan kewirausahaan, serta permasalahan konsistensi internal dari konsep yang digunakan dalam studi yang berbeda.
Dengan demikian, penelitian ini ditujukan untuk mengetahui beberapa aspek yang mengasosiasikan ukuran hasil yang digunakan dalam ciri-ciri kepribadian dan kebutuhan untuk berprestasi.

Penerapan umum ciri kepribadian pada studi kewirausahaan adalah untuk mengasosiasikan ciri-ciri kepribadian dengan kinerja perusahaan. Pada berbagai studi telah digunakan berbagai langkah yang berbeda untuk kinerja perusahaan. Litunan \& Storhammar menggunakan dalam pertumbuhan perusahaan, profit margin perusahaan, dan penilaian keberhasilan diri pengusaha pada keberhasilan perusahaan. Lee dan Tsang mengukur kinerja perusahaan melalui pertumbuhan usaha, sedangkan Jaafar dan Azis mengukur kinerja perusahaan dengan menggunakan kinerja secara keseluruhan. Dari beberapa studi tersebut, terdapat ketidak konsistenan hasil. Isu yang lebih penting adalah akurasi pengukuran kinerja perusahaan pada daya saing aktual perusahaan. Pertanyaan ciri-ciri kepribadian ini disebabkan oleh permasalahan yang berkaitan dengan ciriciri kepribadian atau karena ketidaktelitian variabel dependen yang dipilih. Untuk itu penting meneliti fenomena ini dan mengusulkan penggunaan pandangan berbasis sumber daya di dalam manajemen strategis untuk mempelajari peran ciri-ciri kepribadian dalam menghasilkan keunggulan kompetitif perusahaan kecil dan menengah (UKM). Studi yang dilakukan oleh Kroeck, Bullough, \& Reynold (2010), menunjukkan bahwa internal locus of control 
pada individu dipercaya lebih kuat ke arah entrepreneurial dibandingkan dengan eksternal locus of control. Menurut Farid (2007), locus of control dari mahasiswa MBA di Arab nilainya lebih rendah dibandingkan dengan mahasiswa MBA di Amerika dalam hal pengukuran nilai terhadap uang.

\section{TELAAH PUSTAKA}

\section{Locus of Control (Lokus Kendali)}

Locus of Control merupakan kendali individu atas pekerjaan dan kepercayaan terhadap keberhasilan diri. Lokus pengendalian ini terbagi menjadi dua yaitu lokus pengendalian internal yang mencirikan seseorang memiliki keyakinan bahwa mereka bertanggung jawab atas perilaku kerja mereka pada organisasi, dan lokus pengendalian eksternal yang mencirikan individu yang mempercayai bahwa perilaku kerja dan keberhasilan tugas lebih dikarenakan faktor di luar diri yaitu organisasi.

Locus of control merupakan salah satu variabel kepribadian (personality), yang didefinisikan sebagai keyakinan individu terhadap mampu tidaknya meng ontrol nasib (destiny) sendiri (Kreitner dan Kinicki, 2005). Lokus kendali sebagai tingkat dimana individu yakin bahwa mereka adalah penentu nasib mereka sendiri. Internal adalah individu yang yakin bahwa mereka merupakan pemegang kendali atas apapun yang terjadi pada diri mereka, sedangkan eksternal adalah individu yang yakin bahwa apapun yang terjadi pada diri mereka dikendalikan oleh kekuatan luar seperti keberuntungan dan kesempatan (Robbins \& Judge, 2007).

Kreitner dan Kinichi (2005) menyatakan bahwa hasil yang dicapai locus of control internal dianggap berasal dari aktifitas dirinya. Sedangkan pada individu locus of control eksternal menganggap bahwa keberhasilan yang dicapai dikontrol dari keadaan sekitarnya. Seseorang yang mempunyai internal locus of control akan memandang dunia sebagai sesuatu yang dapat diramalkan, dan perilaku individu turut berperan di dalamnya. Pada individu yang mempunyai external locus of control akan memandang dunia sebagai sesuatu yang tidak dapat diramalkan, demikian juga dalam mencapai tujuan sehingga perilaku individu tidak akan mempunyai peran di dalamnya. Individu yang mempunyai external locus of control diidentifikasikan lebih banyak menyandarkan harapannya untuk bergantung pada orang lain dan lebih banyak mencari dan memilih situasi yang menguntungkan. Sementara itu individu yang mempunyai internal locus of control diidentifikasikan lebih banyak menyandarkan harapannya pada diri sendiri dan diidentifikasikan juga lebih menyenangi keahlian-keahlian dibandingkan hanya pada situasi yang menguntungkan.

\section{Pendekatan Tiga Kebutuhan dari McClelland}

Pendekatan McClelland (1961), mengidentifikasi tiga kebutuhan penting di tempat kerja. Kebutuhan ini dapat dilihat dari berbagai cara.

\section{a. Kebutuhan kekuasaan (nPO )}

Yukl (1989) menelaah hasil teori McClelland dalam memprediksi kepemimpinan. Orang dengan kebutuhan kekuasaan yang rendah, mungkin tidak memiliki kepercayaan diri dan ketegasan yang diperlukan untuk mengatur kegiatan kelompok secara efektif. Kebutuhan tinggi pada kekuasaan dapat dikatakan sebagai kekuatan pribadi. Orang-orang dengan kekuatan pribadi tinggi mungkin memiliki sedikit hambatan atau kontrol diri, dan mereka menjalankan kekuasaan secara impulsif. Ketika mereka memberikan saran atau dukungan, hal itu dimaksudkan strategi untuk lebih meningkatkan status mereka sendiri. Mereka menuntut kesetiaan dari kepemimpinan mereka di dalam organisasi. Kebutuhan kekuasaan paling 
sering dikaitkan dengan kepemimpinan yang efektif. Para pemimpin ini mengarahkan kekuatannya dengan cara yang positif yang menguntungkan orang lain dan organisasi daripada untuk kepentingan dirinya. Mereka mencari kekuasaan, karena melalui kekuasaan semua tugas dapat diselesaikan. Para pemimpin yang efektif memberdayakan orang lain yang menggunakan kekuatan itu untuk memberlakukan dan menjadi visi pemimpin bagi organisasi.

\section{b. Kebutuhan Berprestasi (Nach)}

Prestasi biasanya tercermin dalam cerita untuk mencapai tujuan yang menantang, membuat rekor baru, berhasil menyelesaikan tugas yang sulit, dan melakukan sesuatu yang tidak dilakukan sebelumnya. Berprestasi tinggi perlu lebih memilih pekerjaan di mana kesuksesan tergantung pada usaha dan kemampuan, bukan pada kesempatan dan faktor-faktor di luar kendali mereka (locus of control). Mereka lebih memilih tugas-tugas yang memungkinkan mereka untuk berlatih keterampilan dan inisiasi mereka dalam pemecahan masalah. Mereka ingin sering dan secara spesifik memperoleh umpan balik kinerjanya, sehingga mereka dapat mengetahui dan memiliki pengalaman membuat kemajuan menuju pencapaian tujuan. Skor tinggi sering ditemukan pada pekerjaan seperti perwakilan penjualan, agen real estate, produser acara hiburan, dan pemilik manajer usaha kecil. Bagi manajer dalam organisasi besar, keinginan berprestasi tinggi secara moderat adalah kebutuhan kekuasaan yang lebih tinggi. Jika prestasi merupakan kebutuhan yang dominan, manajer akan mencoba untuk mencapai tujuannya sendiri daripada melalui pengembangan tim.

\section{c. Kebutuhan Afiliasi (Naff)}

Tema Afiliasi terungkap dalam cerita yang membangun atau memulihkan hubungan dekat dan ramah, bergabung dengan kelompok, berpartisipasi dalam kegiatan sosial yang menyenangkan, dan menikmati kegiatan bersama dengan keluarga atau teman. Hal ini mencerminkan perilaku terhadap orang lain yang kooperatif, mendukung, dan ramah dan yang memiliki nilai dan kesesuaian dengan kelompok. Mereka mendapatkan kepuasan besar dari yang disukai dan diterima oleh orang lain, dan lebih memilih untuk bekerja dengan orang lain yang lebih memilin kelompok harmoni dan kohesi. Seseorang yang rendah dalam afiliasi cenderung menjadi penyendiri yang tidak nyaman bersosialisasi dengan orang lain kecuali untuk beberapa teman dekat atau keluarga. Mereka mungkin tidak memiliki motivasi atau energi untuk mempertahankan kontak sosial yang tinggi dalam jaringan, presentasi kelompok, hubungan masyarakat, dan membangun hubungan pribadi yang erat dengan rekan-rekan dan bawahan sangat diperlukan bagi sebagian besar manajer. Naff moderat terkait dengan manajemen yang efektif, karena kebutuhan yang kuat sering menyebabkan menghindari keputusan yang tidak populer, memungkinkan pengecualian terhadap aturan, dan menunjukkan favoritisme kepada teman-teman. Hal ini sering menyebabkan bawahan merasa bingung tentang aturan, dan menjadi cemas tentang apa yang akan terjadi selanjutnya.

\section{Need for Achievement}

McClelland

mengemukakan

karakteristik dan sikap orang memiliki motivasi berprestasi seperti: 
a. Prestasi lebih penting daripada materi atau imbalan keuangan.

b. Mencapai tujuan atau tugas memberikan kepuasan pribadi yang lebih besar daripada menerima pujian atau pengakuan.

C. Imbalan keuangan dianggap sebagai ukuran keberhasilan, bukan tujuan itu sendiri.

d. Keamanan bukan motivator penting, juga bukan status.

e. Umpan balik sangat penting, karena memungkinkan pengukuran keberhasilan, bukan karena alasan pujian atau pengakuan.

f. Orang memiliki motivasi berprestasi mencari perbaikan terus-menerus dan melakukan sesuatu dengan cara yang lebih baik.

Orang memiliki motivasi berprestasi secara logis akan mendukung pekerjaan dan tanggung jawab yang secara alami memenuhi kebutuhan mereka, yaitu menawarkan fleksibilitas dan kesempatan untuk menetapkan dan mencapai tujuan, misalnya, penjualan dan manajemen bisnis, serta peran kewirausahaan.

McClelland menyatakan bahwa orang yang memiliki motivasi berprestasi pada umumnya adalah orang yang membuat sesuatu terjadi dan mendapatkan hasil, dan lebih luas lagi untuk mendapatkan hasil melalui sumber daya dan orang lain, meskipun mereka sering menuntut terlalu banyak dari staf karena memprioritaskan pada pencapaian tujuan di atas banyak kepentingan dan kebutuhan lingkungan mereka.

\section{METODE PENELITIAN}

\section{Populasi dan sampel}

Populasi dalam penelitian ini adalah pengusaha UKM di lingkup Surakarta dan sekitarnya. Sampel dalam penelitian ini adalah pengusaha, manajer atau staf UKM yang bisa ditemui dan bersedia sebagai responden. Teknik pengambilan sampel adalah dengan metode non probability sampling yaitu dengan Convenience sampling.

\section{Instrumen Penelitian dan Pengukuran Variabel Penelitian}

Instrumen dalam penelitian ini adalah kuesioner untuk mengumpulkan data primer dari pengusaha di UKM. Kuesioner untuk kebutuhan berprestasi diadaptasi dari Green (1973), yang terdiri dari 6 butir untuk menilai preferensi pengusaha terhadap tantangan kerja, semangat dan berusaha keras untuk sukses, dan pengorbanan kehidupan pribadi untuk kesuksesan. Sedangkan internal locus of control diadaptasi dari Kaufman et al (1996), terdiri dari 5 item pertanyaan untuk mengukur seberapa jauh individu percaya bahwa kesuksesan. kehidupan, perencanaan dan tingkat kontrol pada dirinya sendiri, dan ditentukan oleh kemampuan mereka sendiri. Instrumen untuk keunggulan kompetitif diri (kebutuhan berprestasi) dikembangkan dan dirujuk dari Wei dan Ismail (2008). Semua item diukur dengan menggunakan 6 titik rentang skala interval biasa dari sangat tidak setuju sampai sangat setuju.

\section{Pengujian dan Analisis Data}

\section{a. Uji Validitas}

Uji validitas yang digunakan dalam penelitian ini adalah teknik Factor Analysis. Secara lebih spesifik, dikarenakan konstruk yang hendak diuji merupakan pengujian kembali dari penelitian yang telah dilakukan sebelumnya, dimana pada penelitian sebelumnya telah berhasil mengidentifikasikan faktor-faktor yang membentuk konstruk, maka dalam penelitian ini teknik analisis yang dipakai adalah menggunakan Confirmatory Factor Analysis (CFA). Dalam penelitian ini CFA diuji dengan bantuan paket perangkat lunak program SPSS 15.0 for Windows. Hair et al., (2006) 
menyatakan bahwa suatu analisis faktor dinyatakan feasible bila memenuhi syarat uji KMO dan Bartlet's Test di atas 0,5 dan signifikansi di bawah 0,05

\section{b. Uji Reliabilitas}

Sekaran (2006), reliabilitas adalah indeks yang menunjukkan sejauh mana alat ukur dapat dipercaya dan sejauh mana hasil pengukuran tetap konsisten bila dilakukan pengukuran dua kali atau lebih terhadap gejala yang sama. Hasilnya ditunjukkan oleh sebuah indeks yang menunjukkan seberapa jauh alat ukur dapat diandalkan (Arikunto, 1996:191). Untuk mengukur reliabilitas dari instrumen penelitian ini dilakukan dengan item-to-total correlation dan Cronbach's Alpha dengan bantuan program komputer SPSS 15.0. Menurut Hair et al., (2006) suatu instrumen dinyatakan reliabel jika hasil koefisien Cronbach's Alpha menunjukkan nilai $\geq 0,70$ dan butir-butir pertanyaan yang ditanyakan reliabel mempunyai item-to-total correlation $\geq$ 0,50 . Meskipun begitu, koefisien Cronbach's Alpha yang berada diantara range 0,6-0,7 masih dapat diterima dan item-to-total correlation $\geq 0,30$ sudah dapat diterima (Sekaran, 2003:311). Item-to-total correlation digunakan untuk memperbaiki pengukuran dan mengeliminasi item-item pertanyaan yang keberadaannya akan memperkecil koefisien Cronbach's Alpha. Skor itemto-total correlation yang lebih kecil dari 0,50 tetap dapat diterima jika butir-butir yang dieliminasi akan menghasilkan koefisien Cronbach's Alpha yang lebih kecil.

\section{c. Analisis Deskriptif}

Analisis Deskriptif adalah metode analisis data dengan cara mengubah data mentah menjadi bentuk yang lebih mudah dipahami dan dintrepretasikan (Zikmund, 2000). Dalam penelitian ini, analisis deskriptif digunakan untuk menganalisis profil responden dan tanggapan responden terhadap setiap item pertanyaan yang mengkaji mengenai ciri-ciri kepribadian dan kebutuhan berprestasi dari para pengusaha, manajer/staf perusahaan UKM di Surakarta dan sekitarnya.

\section{HASI L PEMBAHASAN}

\section{Uji Validitas}

Menurut Hair et al., (2006), factor loading lebih besar \pm 0.30 dianggap memenuhi level minimal, factor loading \pm 0.40 dianggap lebih baik dan sesuai dengan rules of thumb yang dipakai para peneliti, dan factor loading $\geq 0.50$ dianggap signifikan. Jadi semakin besar nilai absolut factor loading, semakin penting loading tersebut menginterpretasikan konstruknya. Pada penelitian ini menggunakan pedoman factor loading $\geq 0,50$ sesuai dengan rules of thumb yang dipakai para peneliti. Berdasarkan pedoman tersebut, peneliti menetapkan factor loading yang signifikan adalah lebih dari sama dengan 0,50. Hasil analisis menunjukkan bahwa semua item pertanyaan dinyatakan valid, karena setiap item pertanyaan yang menjadi indikator masng-masing variabel telah terekstrak secara sempurna dan mempunyai factor loading lebih dari 0,50.

\section{Uji Reliabilitas}

Dalam penelitian ini uji reliabilitas dilakukan menggunakan metode Cronbach's Alpha dengan menggunakan bantuan program SPSS for Windows versi 11.5. Menurut Sekaran (2006) klasifikasi nilai Cronbach's Alpha, sebagai berikut: nilai antara 0,80 - 1,0 dikategorikan reliabilitas baik, nilai antara 0,60 - 0,79 dikategorikan reliabilitas dapat diterima, sedangkan nilai $\leq$ 0,60 dikategorikan reliabilitas buruk. Dari hasil pengujian dapat disimpulkan bahwa semua variabel penelitian dinyatakan reliabel karena mempunyai nilai Cronbach's Alpha $>0,60$. 


\section{Analisis Deskriptif}

Analisis deskriptif dimaksudkan untuk mengetahui karakteristik dan tanggapan responden terhadap item-item pertanyaan dalam kuesioner. Responden dalam penelitian ini adalah pengusaha/manajer/staf perusahaan/ UKM di Surakarta dan sekitarnya. Teknik pengambilan sampel dengan Convenience sampling, yaitu pengusaha/manajer/staf perusahaan yang berhasil ditemui dan bersedia untuk menjadi responden (Sekaran, 2006).

Dalam penelitian ini dibagikan 60 kuesioner kepada pengusaha/manajer/staf
perusahaan/UKM. Dari jumlah tersebut, diperoleh pengembalian kuesioner sebanyak 32 buah atau dengan tingkat partisipasi 53 \%. Dari 32 kuesioner yang kembali ternyata tidak ada yang rusak. Jumlah sampel data yang terkumpul telah memenuhi ukuran sampel minimum yang disyaratkan.

\section{Karakteristik Responden}

Gambaran tentang karakteristik responden diperoleh dari data diri identitas responden yang meliputi jenis kelamin, usia, masa kerja, pendidikan terakhir, anak ke dalam keluarga, dan pekerjaan orang tua.

\section{a. Jenis Kelamin Responden}

Tabel 1. Deskripsi Responden Berdasarkan Jenis Kelamin

\begin{tabular}{|c|c|c|}
\hline Jenis Kelamin & Frekuensi & Persentase \\
\hline Pria & 18 & $56 \%$ \\
\hline Wanita & 14 & $44 \%$ \\
\hline Jumlah & 32 & $100 \%$ \\
\hline
\end{tabular}

Sumber: Data Primer yang diolah

Berdasarkan tabel 1 dapat diketahui bahwa dari 32 responden, $56 \%$ atau 18 responden berjenis kelamin laki-laki dan
$44 \%$ atau 14 responden berjenis kelamin wanita. Sehingga jumlah sampel terbanyak adalah pria.

\section{b. Umur Responden}

Tabel 2. Deskripsi Responden Berdasarkan Umur

\begin{tabular}{|c|c|c|}
\hline Usia (tahun) & Frekuensi & Persentase \\
\hline $21-30$ & 21 & $66 \%$ \\
\hline $31-40$ & 5 & $16 \%$ \\
\hline$>41$ & 6 & $18 \%$ \\
\hline Jumlah & 60 & $100 \%$ \\
\hline
\end{tabular}

Sumber: Data Primer yang diolah

Berdasar tabel 2 di atas dapat diketahui bahwa responden yang berusia antara 21 sampai 30 tahun sebanyak 21 orang atau $66 \%$, usia antara 31 sampai 40 tahun sebanyak 5 orang atau $16 \%$, usia di atas
41 tahun sebanyak 6 orang atau $18 \%$. Dengan demikian dapat disimpulkan bahwa responden terbanyak berusia antara 21 sampai 30 tahun. 


\section{c. Urutan Anak dalam Keluarga Responden}

Tabel 3. Deskripsi Responden Berdasarkan Urutan dalam Keluarga

\begin{tabular}{|c|c|c|}
\hline Anak ke & Frekuensi & Persentase \\
\hline 1 & 13 & $41 \%$ \\
\hline 2 & 6 & $19 \%$ \\
\hline 3 & 6 & $19 \%$ \\
\hline 4 & 2 & $6 \%$ \\
\hline 5 & 3 & $9 \%$ \\
\hline 6 & 1 & $3 \%$ \\
\hline 7 & 1 & $3 \%$ \\
\hline Jumlah & 32 & $100 \%$ \\
\hline
\end{tabular}

Sumber: Data Primer yang diolah

Berdasarkan tabel 3 dapat diketahui bahwa responden yang mempunyai urutan anak dalam keluarga, urutan yang jumlahnya paling banyak masing-masing adalah: anak ke-1; ke-2 dan ke-3; ke-5; ke-4; serta ke-6 dan ke-7; masing-masing sebesar: $41 \%, 19 \%, 9 \%, 6 \%$ dan $3 \%$.

\section{d. Pekerjaan Orang tua Responden}

Tabel 4. Deskripsi Responden Berdasarkan Pekerjaan Orang Tua

\begin{tabular}{|c|c|c|}
\hline Pekerjaan Orang Tua & Frekuensi & Persentase \\
\hline Swasta & 8 & $25 \%$ \\
\hline Wirausaha & 8 & $25 \%$ \\
\hline Pensiunan & 5 & $17 \%$ \\
\hline Petani & 1 & $3 \%$ \\
\hline PNS & 10 & $30 \%$ \\
\hline Jumlah & 32 & $100 \%$ \\
\hline
\end{tabular}

Sumber: Data Primer yang diolah

Berdasarkan tabel 4 dapat diketahui bahwa dari 32 responden, $25 \%$ atau 8 responden masing-masing bekerja Swasta dan Wirausaha, $17 \%$ atau 5 responden orang tuanya Pensiunan, $30 \%$ atau 10 responden orang tuanya PNS, $3 \%$ atau 1 responden orang tuanya adalah Petani.

\section{Tanggapan Responden}

Dalam Analisis ini akan diuraikan mengenai kecenderungan pendapat dan tanggapan dari pemilik/manajer/staf perusahaan selaku responden dalam penelitian ini. Pernyataan-pernyataan responden mengenai variabel penelitian dapat dilihat pada jawaban responden terhadap kuesioner yang diberikan peneliti 
dan pernyataan ini menggunakan skala Likert.

\section{a. Tanggapan Responden Mengenai Kebutuhan untuk Berprestasi}

Deskripsi tanggapan responden sebanyak 32 orang terhadap item pernyataan kebutuhan berprestasi sebanyak 6 item. Dari data kuesioner yang terdapat pada lampiran dapat dilihat deskripsi tanggapan responden pada setiap item pernyataan adalah dalam Tabel 5.

Tabel 5. Deskripsi Tanggapan Responden Terhadap Kebutuhan untuk Berprestasi

\begin{tabular}{|c|l|c|c|c|c|c|}
\hline \multirow{2}{*}{ NO } & \multicolumn{1}{|c|}{ PERNYATAAN } & \multicolumn{5}{c|}{$\begin{array}{l}\text { JAWABAN RESPONDEN } \\
\text { (JUMAH \& PERSENTASE) }\end{array}$} \\
\cline { 3 - 7 } & \multicolumn{1}{|c|}{ SS } & S & N & TS & STS \\
\hline 1 & $\begin{array}{l}\text { Menikmati di dalam melakukan hal- } \\
\text { hal yang menantang }\end{array}$ & $\begin{array}{c}13 \\
(41 \%)\end{array}$ & $\begin{array}{c}16 \\
(50 \%)\end{array}$ & $\begin{array}{c}3 \\
(9 \%)\end{array}$ & 0 & 0 \\
\hline 2 & $\begin{array}{l}\text { Tetap bekerja meskipun orang lain } \\
\text { telah menyerah }\end{array}$ & $\begin{array}{c}16 \\
(50 \%)\end{array}$ & $\begin{array}{c}12 \\
(38 \%)\end{array}$ & $4(12 \%)$ & 0 & 0 \\
\hline 3 & $\begin{array}{l}\text { Senang melakukan pekerjaan yang } \\
\text { menantang }\end{array}$ & $\begin{array}{c}17 \\
(54 \%)\end{array}$ & $\begin{array}{c}11 \\
(34 \%)\end{array}$ & $\begin{array}{c}4 \\
(12 \%)\end{array}$ & 0 & 0 \\
\hline 4 & Menetapkan tujuan yang sulit & $\begin{array}{c}3 \\
(9 \%)\end{array}$ & $\begin{array}{c}11 \\
(34 \%)\end{array}$ & $7(22 \%)$ & 7 & 4 \\
$(22 \%)$ & $(12 \%)$ \\
\hline 5 & $\begin{array}{l}\text { Tidak berkeberatan untuk bekerja, } \\
\text { sementara yang lain bersenang- } \\
\text { senang }\end{array}$ & $7(22 \%)$ & 11 & $7(22 \%)$ & 5 & 2 \\
$(34 \%)$ & & $16 \%)$ & $(6 \%)$ \\
\hline 6 & $\begin{array}{l}\text { Menikmati pekerjaan } \\
(56 \%)\end{array}$ & $\begin{array}{c}14 \\
(44 \%)\end{array}$ & 0 & 0 & 0 \\
\hline
\end{tabular}

Sumber: Data primer yang diolah

1. Berdasarkan data dari tabel di atas menunjukkan bahwa mayoritas responden sebanyak 29 orang atau $91 \%$ menjawab setuju dan sangat setuju atas item pernyataan " Menikmati dalam melakukan pekerjaan yang menantang". Hal ini berarti para manajer, pemilik dan staf sangat menikmati pada pekerjaan yang sangat menantang bagi mereka.

2. Berdasarkan data dari tabel di atas menunjukkan bahwa mayoritas responden sebanyak 28 orang atau $88 \%$ menjawab setuju dan sangat setuju atas item pernyataan "Tetap bekerja meskipun orang lain telah menyerah". Hal ini berarti para pemilik, manajer dan staf UKM memiliki daya juang yang sangat tinggi di dalam melaksanakan pekerjaannya.

3. Berdasarkan data dari tabel di atas menunjukkan bahwa mayoritas responden sebanyak 28 orang atau $88 \%$ menjawab setuju atas item pernyataan "Senang melakukan pekerjaan yang menantang". Hal ini berarti para pemilik, manajer dan taf UKM merasa menikmati dan menyukai pekerjaan-pekerjaan yang menantang bagi mereka.

4. Berdasarkan data dari tabel di atas menunjukkan bahwa mayoritas responden sebanyak 14 orang atau $43 \%$ menjawab setuju dan sangat setuju atas item pernyataan "Menetapkan tujuan yang sulit". Hal ini berarti para pemilik, manajer dan staf UKM di dalam bekerja mereka menetapkan tujuan yang sulit bagi mereka. Walaupun jumlahnya masih di bawah $50 \%$.

5. Berdasarkan data dari tabel di atas menunjukkan bahwa mayoritas responden sebanyak 18 orang atau $56 \%$ menjawab setuju atas item pertanyaan 
"Tidak berkeberatan untuk bekerja, sementara yang lain bersenangsenang". Hal ini berarti para pemilik/ Manajer/ staf perusahaan, mereka merasa melakukan pekerjaan atas kemauan sendiri, walaupun orang lain bersenang-senang, walaupun jumlahnya hanya sedikit di atas $50 \%$.

6. Berdasarkan data dari tabel di atas menunjukkan bahwa seluruh responden sebanyak 32 orang atau $100 \%$ menjawab setuju dan sangat setuju atas item pernyataan "Menikmati pekerjaannya". Hal ini berarti para pemilik/ manajer/ staf perusahaan merasa di dalam melakukan pekerjaannya, mereka merasa nyaman dan sangat menikmati.

\section{b. Tanggapan Responden Mengenai Internal Locus of Control}

Deskripsi tanggapan responden sebanyak 32 orang terhadap item pertanyaan Internal Locus of Control sebanyak 5 item. Dari data kuesioner yang terdapat pada lampiran dapat dilihat deskripsi tanggapan responden pada setiap item pertanyaan adalah dalam Tabel 6.

Tabel 6. Deskripsi Tanggapan Responden Terhadap Internal Locus of Control

\begin{tabular}{|c|c|c|c|c|c|c|}
\hline \multirow[t]{2}{*}{ NO } & \multirow[t]{2}{*}{ PERNYATAAN } & \multicolumn{5}{|c|}{$\begin{array}{l}\text { JAWABAN RESPONDEN } \\
\text { (JUMLAH \& PERSENTASE) }\end{array}$} \\
\hline & & SS & $\mathbf{S}$ & $\mathbf{N}$ & TS & STS \\
\hline 1 & $\begin{array}{l}\text { Percaya pada penentuan kemampuan diri } \\
\text { sendiri }\end{array}$ & $\begin{array}{c}9 \\
(28 \%)\end{array}$ & $\begin{array}{c}20 \\
(63 \%)\end{array}$ & $2(6 \%)$ & $\begin{array}{c}1 \\
(3 \%)\end{array}$ & 0 \\
\hline 2 & $\begin{array}{l}\text { Percaya pada kesuksesan karena } \\
\text { kemampuan dan keterampilan sendiri. }\end{array}$ & $\begin{array}{c}10 \\
(31 \%)\end{array}$ & $\begin{array}{c}15 \\
(47 \%)\end{array}$ & $\begin{array}{c}4 \\
(12 \%)\end{array}$ & $\begin{array}{c}3 \\
(10 \%)\end{array}$ & 0 \\
\hline 3 & Percaya pada kontrol atas rencana sendiri & $\begin{array}{c}9 \\
(28 \%)\end{array}$ & $\begin{array}{c}20 \\
(63 \%)\end{array}$ & $3(9 \%)$ & 0 & 0 \\
\hline 4 & $\begin{array}{l}\text { Percaya pada perlindungan atas } \\
\text { kepentingan diri sendiri }\end{array}$ & $\begin{array}{c}4 \\
(12 \%)\end{array}$ & $\begin{array}{c}16 \\
(50 \%)\end{array}$ & $\begin{array}{c}9 \\
(28 \%)\end{array}$ & $\begin{array}{c}3 \\
(10 \%)\end{array}$ & 0 \\
\hline 5 & $\begin{array}{l}\text { Percaya pada kontrol atas kehidupan } \\
\text { sendiri }\end{array}$ & $\begin{array}{c}6 \\
(19 \%) \\
\end{array}$ & $\begin{array}{c}21 \\
(66 \%)\end{array}$ & $\begin{array}{c}3 \\
(10 \%)\end{array}$ & $\begin{array}{c}2 \\
(5 \%)\end{array}$ & 0 \\
\hline
\end{tabular}

Sumber: data primer yang diolah

1. Berdasarkan data dari tabel di atas menunjukkan bahwa mayoritas responden sebanyak 29 orang atau $91 \%$ menjawab setuju dan sangat setuju atas item pernyataan "Percaya pada penetuan kemampuan diri sendiri". Hal ini berarti para pemilik/manajer/staf merasa bahwa di dalam melaksanakan pekerjaannya mereka merasa percaya pada kemampuan dirinya.

2. Berdasarkan data dari tabel di atas menunjukkan bahwa mayoritas responden sebanyak 25 orang atau $78 \%$ menjawab setuju dan sangat setuju atas item pernyataan "Percaya pada kesuksesan karena kemampuan dan keterampilan sendiri". Hal ini berarti para pemilik usaha/ manajer/staf perusahaan merasa bahwa keberhasilan yang telah mereka capai adalah hasil dari jerih payah mereka sendiri.

3. Berdasarkan data dari tabel di atas menunjukkan bahwa mayoritas responden sebanyak 29 orang atau $91 \%$ menjawab setuju dan sangat setuju atas item pernyataan "Percaya pada kontrol atas rencana sendiri". Hal ini berarti pemilik usaha/manajer/staf perusahaan merasa bahwa mereka memiliki kepercayaan pada manajemen diri atas pekerjaan mereka sendiri. 
4. Berdasarkan data dari tabel di atas menunjukkan bahwa mayoritas responden sebanyak 20 orang atau $62 \%$ menjawab setuju atas item pernyataan "Percaya pada perlindungan atas kepentingan diri sendiri". Hal ini berarti para pemilik/ manajer/ staf perusahaan merasa bahwa di dalam melakukan pekerjaannya, mereka percaya bahwa apa yang mereka lakukan di pekerjaannya adalah benar dan sesuai dengan kepentingan dan tanggung jawabnya.

5. Berdasarkan data dari tabel di atas menunjukkan bahwa mayoritas responden sebanyak 27 orang atau $85 \%$ menjawab setuju dan sangat setuju atas item pernyataan "Percaya pada kontrol atas kehidupan sendiri". Hal ini berarti para pemilik/manajer/staf perusahaan merasa bahwa mereka sangat yakin atas pekerjaannya dan nasib atau keberuntungannya dikendalikan oleh dirinya sendiri.

\section{Pembahasan}

Penelitian yang telah dilakukan oleh Wei dan Ismail (2008), menunjukkan adanya penetapan dasar dan penggiatan kembali peran ciri kepribadian dalam studi kewirausahaan. Review dari beberapa literatur menemukan bahwa terdapat inkonsistensi hasil empiris tentang ciri-ciri kepribadian pada studi kewirausahaan mungkin disebabkan karena pemilihan variabel dependen yang berbeda dalam studi yang berbeda. Keakuratan kinerja perusahaan dalam mengukur dampak kewirausahaan dimungkinkan, karena banyak faktor yang memiliki kemungkinan moderasi pencapaian keuntungan yang tinggi bagi perusahaan. Hal ini menyebabkan diperlukannya keunggulan kompetitif sebagai hasil yang lebih tepat untuk kepribadian dibandingkan dengan kinerja keuangan perusahaan. Studi ini menemukan dan menegaskan bahwa kemungkinan terdapat hubungan antara ciriciri kepribadian dan konsep keunggulan kompetitif. Selain 2 konstruk kepribadian yaitu internal locus of control dan kebutuhan untuk berprestasi, juga ditemukan keterkaitan dengan keunggulan kompetitif perusahaan. Ini merupakan awal adanya dukungan empiris untuk meningkatkan penelitian ini. Bukti empiris dalam penelitian ini yang mendasari kesimpulan penelitian. Selanjutnya diperlukan replikasi dari studi ini pada lokasi geografis yang berbeda atau dengan menambahkan ciri-ciri kepribadian yang lebih pada penelitian ke depan.

\section{Simpulan}

\section{SIMPULAN}

Simpulan dari studi ini adalah, dari karakteristik responden ditemukan bahwa: 1). Sebagian besar responden (56\%) adalah pria, 2). Sebanyak $66 \%$ berusia pada rentang 21-30 tahun, 3). Mayoritas responden $(41 \%)$ merupakan anak pertama di dalam keluarganya, 4). Secara berturutturut, sebanyak 30\% responden, orang tuanya bekerja sebagai PNS, masing-masing sebanyak $25 \%$ bekerja di perusahaan swasta dan berwirausaha.

Dari deskripsi responden: 1). Pada kebutuhan untuk berprestasi, a). seluruh responden (100\%) menikmati pekerjaannya, b). sebanyak $91 \%$ dari responden menikmati dalam melakukan pekerjaan yang menantang, c). sebagian besar dari responden (masing-masing sebanyak $88 \%$ ) menyatakan tetap melakukan pekerjaannya meskipun orang lain telah menyerah, dan senang melakukan pekerjaan yang menantang, dan d). sebagian besar responden (sebanyak 56\%) menyatakan tidak berkeberatan untuk bekerja, sementara yang lain bersenang-senang.

Dari deskripsi responden: 2). Pada internal locus of control ditemukan bahwa, a). masing-masing sebanyak $91 \%$ dari responden menyatakan percaya pada penentuan kemampuan diri sendiri, serta 
percaya pada kontrol atas rencana sendiri, b). sebanyak $85 \%$ menyatakan percaya pada kontrol atas kehidupan sendiri, c). yang menyatakan percaya pada kesuksesan karena kemampuan dan keterampilan sendiri sebanyak $78 \%$ dari seluruh responden, dan d). sebanyak $62 \%$ menyatakan percaya pada perlindungan atas kepentingan diri sendiri.

\section{Implikasi Manajerial}

Temuan dalam penelitian ini telah menghidupkan kembali peran ciri kepribadian dalam studi kewirausahaan. Dengan demikian, berbagai rekomendasi dapat diteruskan kepada pembuat kebijakan dan pengusaha. Bagi pembuat kebijakan, perlu dilakukan agar dapat memperkuat ciri-ciri kepribadian dari calon pengusaha. Antara lain, pemerintah dapat mempertimbangkan untuk mengubah sistem pendidikan dengan berbagai pelatihan yang dapat memperkuat ciri-ciri kepribadian seorang individu. Karena kebutuhan untuk berprestasi dan internal locus of control dari pengusaha sangat penting untuk mencapai keunggulan kompetitif bagi UKM, mereka harus mendapatkan pembelajaran tentang ini sejak dini. Muatan kurikulum yang dimasukkan di dalam sistem pendidikan, untuk memberikan penekanan lebih besar pada perkembangan kepribadian pengusaha. Instruktur dapat menilai motivasi peserta dalam mengorganisir kegiatan kerja termasuk kepercayaan diri dan sikap mereka dalam meng hadapi rintangan.

Bagi para pengusaha/UKM, serta yang ingin menjadi pengusaha, temuan penelitian ini dapat dijadikan acuan untuk mengevaluasi kompetensi diri. Para pengusaha perlu memiliki kesadaran diri atas ciri-ciri kepribadian mereka sendiri. Dalam jangka pendek, bagi pengusaha dan mereka yang ing in menjadi pengusaha/UKM dapat mempertimbangkan untuk melibatkan mitra/manajer ataupun staf yang dapat melengkapi kelemahan mereka. Dalam jangka panjang, pengusaha harus melakukan sendiri termasuk menghadiri pelatihan untuk meningkatkan kepribadian mereka agar dapat mengembangkan pribadi dan usaha mereka dengan pengembangan karir mereka.

\section{DAFTAR PUSTAKA}

Arikunto. 2002. Prosedur Penelitian: Suatu Pendekatan Praktek. Edisi Revisi V. Jakarta. Rineka Cipta.

Farid, Mamdouh. 2007. The Relevance of Transition to Free Market, Attitude Towards Money, Locus of Control, and Attitude Towards Risk to Entrepreneurs: A Cross Cultural Empirical Comparison. International Journal of Entrepreneurship. 11, pp.7590.

Green, JB. 1973. Need for Achievement, Need for Affiliation and The Adjustment of High School Students. Tasler Thesis: University of Windsor.

Hair; Anderson; Tatham and Black. 2006. Multivariate Data Analysis. Six Edition, New Jersey: Pearson Educational, Inc.

Kaufmann,PJ; Welsh, RHB; Bushmarin, NV. 1996. Locus of Control and Entrepreneurship in the Russian Republic. Entrepreneurship Theory \& Practice.

Kreitner \& Kinicki. 2005. Perilaku Organisasi. Jakarta. Salemba Empat.

Kroeck, Bullough, \& Reynold. 2010. Entrepreneurship \& Differences in Locus of Control. The Journal of Applied Management \& Entrepreneurship. Vol.15, No.1, pp.21-50. 
McClelland. 1961. The Achieving Society. Van Nostrand Reinhold. Princeton. New Jersey.

Robbins \& Judge. 2007. Organizational Behavior. Prentice Hall Inc.

Sekaran, Uma. 2006. Metodologi Penelitian untuk Bisnis 2. Edisi 4. Jakarta. Salemba Empat.
Wei \& Ismail. 2008. Revisiting Personality Traits in Entrepreneurship Study from Resource Based Perspective. Business Renaissance Quarterly. 3 (1).p.97.

Yukl, Gary. Leadership in Organization. 8 edition.

Zikmund, WG. 2000. Business Research Method. Fourth Edition. The Dryden Press. Harcourt College Publisher. 
